\title{
YIELD POTENTIAL IMPROVEMENT OF SOME LOWLAND RED RICE LINES IN F4 PEDIGREE SELECTION
}

\author{
Suliartini Ni Wayan Sri ${ }^{\star}$, Aryana I Gusti Putu Muliarta, \\ Sudharmawan Anak Agung Ketut, Wangiyana Wayan \\ Faculty of Agriculture, University of Mataram, Mataram, Indonesia \\ *E-mail: sri.suliartini@gmail.com
}

\begin{abstract}
This study aimed to obtain F4 lines of red rice with high yield potential, high number of filled grains and early maturity compared to their parents (F2BC4P19-36, Fatmawati and IPB 3S varieties) through Pedigree selection. To make statistical comparison, the results of the Pedigree selection were grown together with those parents in the Experimental Farm of the Faculty of Agriculture, University of Mataram, located in Narmada, West Lombok (Indonesia), from April to August 2020. The experiment was arranged according to a Randomized Complete Block Design, with 13 treatments consisting of 10 lines resulted from the Pedigree selection and their three parents. The experiment was made in three blocks as the replicates. The results showed that the F4 IPB3S/F2BC4P19-63//Fat/F2BC4P19-63-PD3/13 line showed an average dry grain yield of $40.49 \mathrm{~g} / \mathrm{clump}$, which was significantly higher than that of the Fatmawati variety $(31.53 \mathrm{~g} / \mathrm{clump})$, but it was not significantly higher than the other parents, namely IPB 3S (35.40 g/clump) and the promising line F2BC4P19-36 (38.66 $\mathrm{g}$ /clump). In addition, the average filled grain number per panicle was also high while it was still in the category of early maturity. Thus, it can be concluded that the F4 IPB3S/F2BC4P19-63//Fat/F2BC4P19-63-PD3/13 line resulted from the Pedigree selection is highly potential to be bread further to develop a promising line of lowland red rice with high yield potential, high number of filled grains per panicle but early maturity.
\end{abstract}

\section{KEY WORDS}

Lowland red rice, high yield potential, early maturity, F4 lines, Pedigree selection.

Rice is a staple food for almost all Asian people and is an important staple food in the world besides wheat and corn [1]. Rice contributes up to $20 \%$ of global energy intake [2], so the demand for rice is predicted to continue to increase in line with the increase in the world's population [3]. Therefore, genetic improvement in rice cultivars needs to be done to be able to increase rice productivity in an effort to meet the increasing demand for rice.

Genetic improvement of rice, including red rice, is increasingly important with increasing public awareness of the importance of health. Red rice contains carbohydrates, protein, vitamins, fiber and minerals ( $\mathrm{Fe}, \mathrm{Zn}, \mathrm{Mn}, \mathrm{P})$ which are higher in red than in white rice [4]. Red rice, in addition to having a high nutritional content, also contains anthocyanins [510]. The experimental results showed that anthocyanins in rice were identified as cyanidin 3O-glucoside $(66.1 \pm 10.6 \mathrm{~g} / \mathrm{g})$ [4]. An important property of anthocyanins is their antioxidant activity, which plays an important role in the prevention of neurological diseases as well as cancer and diabetes [11-12].

Sources of new genes that have the potential to be developed towards the formation of superior varieties of red rice with high yield potential, early maturity and high number of filled grains per panicle are urgently needed, considering that there are still many germplasms for these traits that have not been identified. Based on the results of research conducted by Aryana et al. [13] by back-crossing as much as 4 (four) times between drought tolerant red rice lines and local cultivars of red rice "Kala Isi Tolo", which has high anthocyanin content and early maturity, the promising line of upland red rice F2BC4P19-36 has been produced which has a high anthocyanin content, a large number of tillers, early maturity (107 days) but still has a relatively low yield of 5.8 ton/ha. This line was then crossed with "IPB 3S" variety (which has a potential yield of 11.2 ton/ha, 112 days to maturity, fluffy texture of the cooked 
rice with white rice color, but with a small number of tillers) and "Fatmawati" variety (which has a potential yield of 9 ton/ha, 115 days to maturity with fluffy texture of the cooked rice with white rice color, but only few tillers), through single cross and repeated cross selection, followed by pedigree selection until F3 to produce various superior red rice lines. The diversity that still exists in the population of the F3 lines still requires further selection to select uniform genotypes and separate non-uniform genotypes [14].

Pedigree selection is a selection method applied to segregated populations or populations that are still not uniform [15]. This selection requires detailed recording of the initial generation of the generation separation. Selection stages in each generation are carried out to obtain superior genotypes at each selection stage. Superior genotypes in the selection of the second generation (F2) will be re-selected in the next generation. Segregation of the crosses will occur in the F2 to F6 generations, so that the selection begins in the F2 generation and continues in the next generations until a homogeneous, homozygous pure line is obtained. The advantage of this selection is that only lineages that have the desired or superior genes will be carried over to the next generation [16]. The selection stages of this fourth generation aimed to obtain uniform red rice lines, which have high yield potential, high number of filled grains and early maturity. The yield potential of the selected lines was expected to be higher than that of the parents (F2BC4P19-36 promising line, Fatmawati variety and IPB 3S variety).

\section{MATERIALS AND METHODS OF RESEARCH}

There were 13 genotypes used as the treatments in the field experiment conducted from April to July 2020 at the Experimental Farm of the Faculty of Agriculture, University of Mataram, located in Narmada (West Lombok, Indonesia), which consisted of 10 lowland red rice lines resulted from the Pedigree selection of F3 (F2 IPB3S/F2BC4P19-63// Fat/F2BC4P19-63-PD3) and their parents ("Fatmawati" variety, "IPB 3S" variety and the promising line of red rice "F2BC4P19-36"). The experiment was arranged according to the Randomized Complete Block Design with three blocks as the replications, so that there were 39 experimental units. The names of the genotypes tested are listed in Table 1.

Table 1 - Genotype name of those lines resulted from Pedigree selection

\begin{tabular}{ll}
\hline Treatments & Genotypes \\
\hline G1 & F4 IPB3S/F2BC4P19-63// Fat/F2BC4P19-63-PD3/7 \\
G2 & F4IPB3S/F2BC4P19-63// Fat/F2BC4P19-63-PD3/15 \\
G3 & F4 IPB3S/F2BC4P19-63// Fat/F2BC4P19-63-PD3/20 \\
G4 & F4 IPB3S/F2BC4P19-63// Fat/F2BC4P19-63-PD3/13 \\
G5 & F4 IPB3S/F2BC4P19-63// Fat/F2BC4P19-63-PD3/71 \\
G6 & F4 IPB3S/F2BC4P19-63// Fat/F2BC4P19-63-PD3/94 \\
G7 & F4 IPB3S/F2BC4P19-63// Fat/F2BC4P19-63-PD3/34 \\
G8 & F4 IPB3S/F2BC4P19-63// Fat/F2BC4P19-63-PD3/44 \\
G9 & F4 IPB3S/F2BC4P19-63// Fat/F2BC4P19-63-PD3/31 \\
G10 & F4 IPB3S/F2BC4P19-63// Fat/F2BC4P19-63-PD3/81 \\
G11 & Fatmawati variety (parents) \\
G12 & IPB 3S variety (parents) \\
G13 & F2BC4P19-36 promising line (parents) \\
\hline
\end{tabular}

Data were analyzed using analysis of variance (ANOVA) at $5 \%$ level of significance, followed with Duncan Multiple Range Test (DMRT) at the same significance level as for means comparison using the SAS program.

\section{RESULTS AND DISCUSSION}

Based on the ANOVA results listed in Table 2, the 13 genotypes tested were significantly different in all observation variables. In terms of the maturity dates, all the lowland red rice lines resulted from the Pedigree selection are in the category of early maturity because the number of days to harvest ranged from 115.7 days after seeding (DAS) 
in G8 to 127.0 DAS in G3. According to the BB Padi [17], maturity dates of rice plants are categorized into six categories of maturity: (1) Ultra early maturity (less than 90 days); (2) Very early maturity (90-104 days); (3) Early maturity (105-124 days); 4) Medium maturity (125-150 days); and (5) Late maturity (more than 150 days). Based on these groupings, the tested lowland red rice lines are in the category of early maturity, except for G3.

Table 2 - Results of means comparison among the genotypes tested for all observation variables

\begin{tabular}{|c|c|c|c|c|c|c|c|c|c|c|c|c|c|c|}
\hline \multirow{2}{*}{$\begin{array}{l}\text { Treatments } \\
\text { G1 }\end{array}$} & \multicolumn{2}{|l|}{$\begin{array}{l}\text { Days to } \\
\text { harvest }\end{array}$} & \multicolumn{2}{|c|}{$\begin{array}{l}\text { Panicle number } \\
\text { per clump }\end{array}$} & \multicolumn{2}{|c|}{$\begin{array}{l}\text { Panicle length } \\
(\mathrm{cm})\end{array}$} & \multicolumn{2}{|c|}{$\begin{array}{l}\text { Filled grains per } \\
\text { panicle }\end{array}$} & \multicolumn{2}{|c|}{$\begin{array}{l}\text { Unfilled grains } \\
\text { per panicle }\end{array}$} & \multicolumn{2}{|c|}{$\begin{array}{l}\text { 100-grain } \\
\text { weight }(\mathrm{g})\end{array}$} & \multicolumn{2}{|c|}{$\begin{array}{l}\text { Dry grain yield } \\
\text { (g/clump) }\end{array}$} \\
\hline & 117.7 & $b$ & 10.60 & de & 23.87 & $a b$ & 152.43 & cde & 21.53 & $a b c$ & 2.85 & bcd & 31.45 & bc \\
\hline G2 & 116.3 & $b$ & 13.17 & bcde & 20.67 & c & 143.13 & de & 10.50 & $\mathrm{~cd}$ & 2.66 & de & 31.78 & bc \\
\hline G3 & 127.0 & $a$ & 14.47 & bcd & 24.33 & $a b$ & 159.93 & bcd & 26.00 & $a b c$ & 2.83 & $\mathrm{~cd}$ & 31.01 & bc \\
\hline G4 & 120.7 & $a b$ & 10.43 & de & 24.23 & $a b$ & 201.81 & $a$ & 27.63 & $a b$ & 2.97 & $a b c$ & 40.49 & a \\
\hline G5 & 116.0 & $b$ & 9.93 & e & 23.43 & $b$ & 169.87 & bcd & 11.57 & bcd & 2.58 & e & 31.15 & bc \\
\hline G6 & 121.0 & $a b$ & 10.53 & de & 24.67 & $a b$ & 158.70 & bcd & 21.27 & $a b c$ & 3.04 & $a b c$ & 29.79 & $\mathrm{C}$ \\
\hline G7 & 120.3 & $a b$ & 10.93 & de & 24.63 & $a b$ & 172.90 & bcd & 27.80 & $a b$ & 2.96 & $b c$ & 32.17 & bc \\
\hline G8 & 115.7 & $b$ & 21.77 & $\mathrm{a}$ & 18.87 & $d$ & 93.13 & $f$ & 4.30 & d & 2.56 & e & 33.25 & $a b c$ \\
\hline G9 & 119.7 & $\mathrm{~b}$ & 12.67 & bcde & 24.67 & $a b$ & 182.47 & $a b$ & 17.17 & abcd & 2.88 & bcd & 35.48 & $a b c$ \\
\hline G10 & 121.3 & $a b$ & 16.00 & bcde & 23.60 & $a b$ & 155.30 & bcde & 20.27 & abcd & 3.23 & a & 36.49 & $a b c$ \\
\hline G11: Fatma & 119.3 & $b$ & 15.40 & bc & 21.67 & c & 129.57 & $\mathrm{e}$ & 27.63 & $a b$ & 2.89 & bcd & 31.53 & bc \\
\hline G12: IPB & 118.3 & $b$ & 11.73 & cde & 24.67 & $a b$ & 143.57 & de & 32.90 & a & 2.99 & $a b c$ & 35.40 & $a b c$ \\
\hline G13: F2B & 122.0 & $a b$ & 9.23 & $\mathrm{e}$ & 25.53 & $\mathrm{a}$ & 177.17 & $a b c$ & 12.87 & bcd & 3.11 & $a b$ & 38.66 & $a b$ \\
\hline ANOVA & $\mathrm{s}$ & & $\mathrm{s}$ & & $\mathrm{s}$ & & $\mathrm{s}$ & & $\mathrm{s}$ & & $\mathrm{s}$ & & $\mathrm{s}$ & \\
\hline
\end{tabular}

Among the observed characters (Table 2), the grain yield is the ultimate goal of breeding activities for rice plants. Plants that have resistance to various biotic and abiotic factors but have low yields will not have the potential to be developed into superior varieties. Some of the lowland red rice lines tested had grain yield per clump ranging from 29.79 $\mathrm{g} /$ clump (or $4.77 \mathrm{ton} / \mathrm{ha}$ ) in G6 to $40.49 \mathrm{~g} / \mathrm{clump}$ (or $6.48 \mathrm{ton} / \mathrm{ha}$ ) in G4. Dry grain yield of G4 was higher than that of "Fatmawati" variety $(31.53 \mathrm{~g} / \mathrm{clump}$ or $5.05 \mathrm{ton} / \mathrm{ha})$ as one parent but the same as that of "IPB $3 S$ " variety $(35.40 \mathrm{~g} / \mathrm{clump}$ or $5.66 \mathrm{ton} / \mathrm{ha})$ and the promising line "F2BC4P19-36" (38.66 $\mathrm{g} / \mathrm{clump}$ or $6.19 \mathrm{ton} / \mathrm{ha}$ ) as the other two parents. Therefore, quantitatively the average yield of G4 was higher than the three parents, but statistically the productivity of G4 was only higher than that of the Fatmawati variety.

The results of research by Muliarta et al. [13] support the results of this study, where the productivity of G4 was higher than its parent F2BC4P19-36 (5.8 ton/ha). The potential yield of G4 was also higher than several genotypes of red rice tested with the SRI system, namely Mayam U 32 (6.1 ton/ha), Ramos Tihion 18 (5.9 ton/ha), Ketan Mirah 2 (6.0 ton/ha), Lamno 6 (4.6 ton/ha), Sirias 102 (5.5 ton/ha) and Sigodok 201 (4.3 ton/ha) [18].

The high yield in the G4 line (F4 IPB3S/F2BC4P19-63//Fat/F2BC4P19-63-PD3/13) was supported by medium number of productive tillers (10.63 tillers/clump), long panicle (24.23 $\mathrm{cm}$ ), high number of filled grains (201.81 grains/panicle) and a high weight of 100 grains $(2.97 \mathrm{~g})$. Based on the research results of Widyastuti et al. [19], the number of productive tillers and the number of filled grains per panicle were the characteristics of the yield selection criteria in rice. The yield of the G4 line was higher than that of Southeast Sulawesi local red rice of $18.14 \mathrm{~g} /$ clump reported by Nuraida et al. [20], but still lower than the SSJ31.6-21 line (64.90 g/clump) as a result of mutation treatment reported by Suliartini et al. [10].

The ideal type of rice requires a moderate number of productive tillers (8-10 tillers per clump). According to Prayoga et al. [21], the large number of tillers per clump will also affect intra-species competition for natural resources such as water, $\mathrm{CO}_{2}, \mathrm{O}_{2}$, nutrients, light and space to grow. This opinion is in line with Wang et al. [22] that the uneven distribution of photo-synthetically active radiation (PAR) causes variations in the number of grain per tiller because the tillers that appear earlier are superior tillers that shade the tillers below them. Among the lowland red rice lines tested in this study, there were three lines having 9-10 tillers, namely G4, G5 and G13. These lines have the potential to be developed into superior lines of ideal rice type.

Panicle length is influenced by a combination of genetic and environmental factors [23]. Sharma et al. [24] revealed that this character indicates whether the yield is high or low. 
Longer panicles tend to have a higher number of grains per panicle than a shorter one. From the results of this study, the average length of the panicle ranged from $18.87 \mathrm{~cm}$ on G8 to $25.53 \mathrm{~cm}$ on G13. The results of research by Haryanto et al. [25] showed that in addition to the number of productive tillers, weight of 1000 grains and number of tillers, panicle length also affected rice grain yield. There is a positive correlation between panicle length and 1000 grain weight which affects rice grain yield [26].

The filled grain number in several lowland red rice lines in this study varied widely, ranging from 93.13 in G8 to 201.81 in G4. The number of filled grains in the G4 line was higher than the number of filled grains reported by Sadimantara et al. [27] for four upland lines of cross-bred red rice. The higher the filled grain number, the higher the grain yield of rice [28], [29]. A high number of filled grains must also be supported by a low number of unfilled grains. These two characters, namely the numbers of filled grains and unfilled grains were influenced by genetic factors that caused differences between the tested lines. However, the diversity of these characters, in addition to being caused by genetic factors, the difference in the number of filled grains and the number of unfilled grains per panicle is also influenced by environmental factors [27]. The diversity of the number of filled grain was followed by the diversity of the number of unfilled grains ranging from 4.3 in G8 to 32.9 in G12. According to Sadimantara et al. [27], rice production is determined by the number of grain per panicle, grain weight and number of productive tillers per unit area.

The weight of 100 grains indicates the size of the grain. The higher the weight of 100 grains, the higher the grain size. The weight of 100 grains of red rice in this study ranged from $2.56 \mathrm{~g}$ in G8 to $3.23 \mathrm{~g}$ in G10. The weight of the highest 100 grains of the 13 genotypes tested was higher than the weight of the highest 100 grains of the 4 lines of red rice reported by Sadimantara et al. [27] but lower than the weight of the highest 100 grains reported by Suliartini et al. [8]. Rice plants with a high weight of 100 grains will have high yields because there is a positive correlation between the weight of 100 grains and grain yields [26], [27].

The results of this study indicate that the Pedigree selection on F4 was able to produce a line that is better than one parent, i.e. "Fatmawati" variety but not significantly better than the other two parents, namely "IPB 3S" variety and the "F2BC4P19-36" promising line. The results of this research needs to be tested further because the previous generation of pedigree selection showed that grain yield of G4 was higher than that of the "F2BC4P19-36" promising line.

\section{CONCLUSION}

It can be concluded that the F4 IPB3S/F2BC4P19-63// Fat/F2BC4P19-63-PD3/13 line has the potential to be developed further into a promising line of lowland red rice with a high yield potential, high number of filled grains and early maturity through further testing on F5 Pedigree selection.

\section{ACKNOWLEDGEMENTS}

This research was funded by the Faculty of Agriculture, the University of Mataram through "PNBP" research funding of the 2021 budget year.

\section{REFERENCES}

1. Zhang, Y., Jiang, Y., Tai, A.P.K., Feng, J., Li, Z., Zhu, X., Chen, J., Song, Z., Deng, A., Lal, R., and Zhang, W. 2019. Contribution of rice variety renewal and agronomic innovations to yield improvement and greenhouse gas mitigation in China. Environ. Res. Lett., 14114020.

2. Nuryani. 2013. Potensi subtitusi beras putih dengan beras merah sebagai makanan pokok untuk perlindungan diabetes melitus. Media Gizi Masyarakat Indonesia, 3(3): 157168. 
3. Seck, P.A., Diagne, A., Mohanty, S., and Wopereis, M.C. 2012 Crops that feed the world 7: Rice. Food Security, 4: 7-24.

4. Apridamayanti, P., Pratiwi, R., Purwestri, Y.A., Tunjung, W.A.S., and Rumiyati. 2017. Anthocyanin, nutrient contents, and anoxidant acvity of black rice bran of Oryza sativa L. 'Cempo Ireng' from Sleman, Yogyakarta, Indonesia. Indones. J. Biotechnol., 22(1): 4954.

5. Suliartini, N.W.S., Sadimantara,G.R., Wijayanto, T., and Muhidin. 2011. Pengujian antosianin padi gogo beras merah hasil koleksi plasma nutfah Sulawesi Tenggara. Crop Agro., 4 (2): 43-48.

6. Suliartini, N.W.S., Kuswanto, Basuki, N., and Soegianto, A. 2015. The sensitivity of two Southeast Sulawesi local red rice varieties to gamma irradiation. IOSR-JESTFT, 9(9): 2431.

7. Suliartini, N.W.S., Wijayanto, T., Madiki, A., Boer, D., Muhidin, and Tufaila, M. 2018a. Yield potential improvement of upland red rice using gamma irradiation on local upland rice from Southeast Sulawesi Indonesia. Bioscience Research, 15(3):1673-1678.

8. Suliartini, N.W.S., Kuswanto, Basuki, N., and Soegianto, A. 2016. Superior lines candidates evaluation of two local red rice Southeast Sulawesi cultivars (Indonesia) derived from gamma rays irradiation techniques. International Journal of Plant Biology, 7(6475): 64-67.

9. Suliartini, N.W.S., Wijayanto, T., and Madiki, A. 2018b. Pengembangan padi gogo beras merah hasil irradiasi gamma berproduksi tinggi yang berumur genjah dan tahan kekeringan melalui seleksi pedigree. Laporan Penelitian Strategis Nasional (PSN) Institusi Tahun Ke-2. Universitas Halu Oleo.

10. Suliartini, N.W.S., Aryana, I.G.P.M., Wangiyana, W., Ngawit, I.K., Muhidin and Rakian, T.C. 2020. Identification of upland red rice mutant lines (Oryza sativa L.) high yield potential. IJSTR, 9 (03): 4690-4692.

11. Konczak, I., and Zhang, W. 2004. Anthocyanins-more than nature's colours (2004). Journal of Biomedicine and Biotechnology, 5: 239-240.

12. Castañeda-Ovando, A., Pacheco-Hernández, M.L., Páez-Hernández, M.E., Rodríguez, J.A., Galán-Vidal, C.A. 2009. Chemical studies of anthocyanins: A review. Food Chemistry, 113: 859-871.

13. Aryana, I.G.P.M., Sudanta, I.M., and Santoso, B.B. 2013. Pengembangan padi gogo beras merah potensi hasil tinggi dengan kandungan antosianin tinggi. Laporan penelitian insentif Riset Sinas RT-2013-119 . Teknologi Pangan, Riset Terapan. 60 h.

14. Aryana, I.G.P.M., Santoso, B.B., and Kisman, 2017. Perakitan varietas padi gogo rancah beras merah fungsional tipe baru potensi hasil tinggi ( $>7$ ton/ha) serta berumur genjah (< 115 hari). Laporan Penelitian Strategis Nasional Tahun 3.

15. Wardani, S., Wirnas, D., and Wahyu, Y. 2015. Seleksi segregan gandum (Triticum aestivum L.) pada dataran tinggi. J. Agron. Indonesia, 43 (1): 45 - 51.

16. Dewi, E.S. 2016. Pemuliaan tanaman. Fakultas Pertanian Universitas Malikussaleh. 68 hal. https://repository.unimal.ac.id/

17. BB Padi Litbang Pertanian. 2015. Klasifikasi umur padi. http://bbpadi.litbang.pertanian.go.id/index.php/tahukah-anda/120-kalsifikasi-umur-padi.

Download July 27, 2015.

18. Efendi, Syamsuddin, and Agustina, B. 2016. Performansi genotip padi beras merah dari varietas lokal aceh yang dibudidayakan secara aerobik pada sistem sri organik. In English: Performance of red rice genotype from aceh's province that cultivated with aerobic system in organic sri. J. Floratek, 11 (1): 51-58.

19. Widyastuti, Y., Satoto, S., and Rumant, I.A. 2015. Performance of promising hybrid rice in two different elevations of irrigated lowland in Indonesia. AGRIVITA, 37 (2): 169-177. http://dx.doi.org/10.17503/Agrivita-2015-37-2-p169-177.

20. Nuraida, W.O., Pradipta, R.P., Suliartini, N.W.S., Wijayanto, T., Muhidin and Sadimantara, G.R. 2020. Production and quality of upland red rice under the shade stress. IJSTR, 9(03): 5016-5019. 
21. Prayoga, M.K., Rostini, N., Setiawati, M.R., Simarmata, T., Stoeber, S. and Adinata, K. 2018. Preferensi petani terhadap keragaan padi (Oryza sativa) unggul untuk lahan sawah di wilayah Pangandaran dan Cilacap. In Inglish:Preferences of farmers to superior rice (Oryza sativa) for rice fields inPangandaran and Cilacap regions. Jurnal Kultivasi, 17(1): 523-530.

22. Wang, Y., Ren, T., Lu, J.W., Ming, R., Li, P.F., Saddam, H., Cong, R.H. and Li, X.K. 2016. Heterogeneity in rice tillers yield associated with tillers formation and nitrogen fertilizer. Agronomy Journal, 108: 1717-1725.

23. Bahua, M.I. and Gubali, H. 2020. Direct seed planting system and giving liquid organic fertilizer as a new method to increase rice yield and growth (Oryza sativa L.). AGRIVITA, 42(1): 68-77.

24. Sharma, G., Giri, J., and Tyagi, A.K. 2016. Subfunctionalization in rice gene families with regulatory roles in abiotic stress responses. Critical Reviews in Plant Sciences, 35(4), 231-285. https://doi.org/10.1080/07352689.2016.1265357.

25. Haryanto, T.A.D., Suwarto and Yoshida, T. 2008. Yield stability of aromatic upland rice with high yielding ability in Indonesia. Plant Prod. Sci., 11: 96-103.

26. Akinwale, M.G., Gregorio, G., Nwilene, F., Akinyele, B.O., Ogunbayo, S.A. and Odiyi, A.C. 2011. Heritability and correlation coefficient analysis for yield and its components in rice (Oryza sativa L.). Afr. J. Plant. Sci., 5 (3): 207-212.

27. Sadimantara, G.R., Nuraida, W., Suliartini, N.W.S., and Muhidin. 2018. Evaluation of some new plant type of upland rice (Oryza sativa L.) lines derived from cross breeding for the growth and yield characteristics. IOP Conf. Ser.: Earth Environ. Sci., 157: 1-6.

28. Hossain, M.F., Bhuiya, M.S.U., and Ahmed, M. 2005. Morphological and agronomic attributes of some local and modern aromatic rice varieties of Bangladesh. Asian J. Plant Sci., 4: 664-666.

29. Tun, T.N., Guo, J., Fang, S., and Tian, Y., 2018. Planting spasing affects canopy structure, biomass production and stem roundness in poplar plantations. Scandinavian Journal of Forest Research, 33(5), 464-474. https://doi.org/10.1080/02827581.2018.1457711. 